\title{
Policy and impact of public museums in China : exploring new trends and challenges
}

\author{
Bollo, Sofia ; Zhang, Yu
}

\begin{abstract}
In a commercialised and globalised China, museum institutions are pivotal elements in public strategies to present and create national self-consciousness, insofar as their vast collections provide symbols of cultural identification on a national as well as an international level. This article will explore Chinese public museum policy and impact, firstly by describing the current status of the system as background information; secondly, by presenting the most recent trends in museum strategies and finally, by replacing the challenges and complexities of the museum system in a broader context. The analysis will draw from first hand material from interviews and informal conversations with museum professionals, small-scale visitor surveys as well as the most recent facts and figures, and it will be illustrated by examples and supported by secondary sources.
\end{abstract}

DOI: https://doi.org/10.1111/muse.12170

Posted at the Zurich Open Repository and Archive, University of Zurich ZORA URL: https://doi.org/10.5167/uzh-180940

Journal Article

Published Version

The following work is licensed under a Publisher License.

Originally published at:

Bollo, Sofia; Zhang, Yu (2017). Policy and impact of public museums in China : exploring new trends and challenges. Museum International, 69(3-4):26-37.

DOI: https://doi.org/10.1111/muse.12170 


\section{Policy}
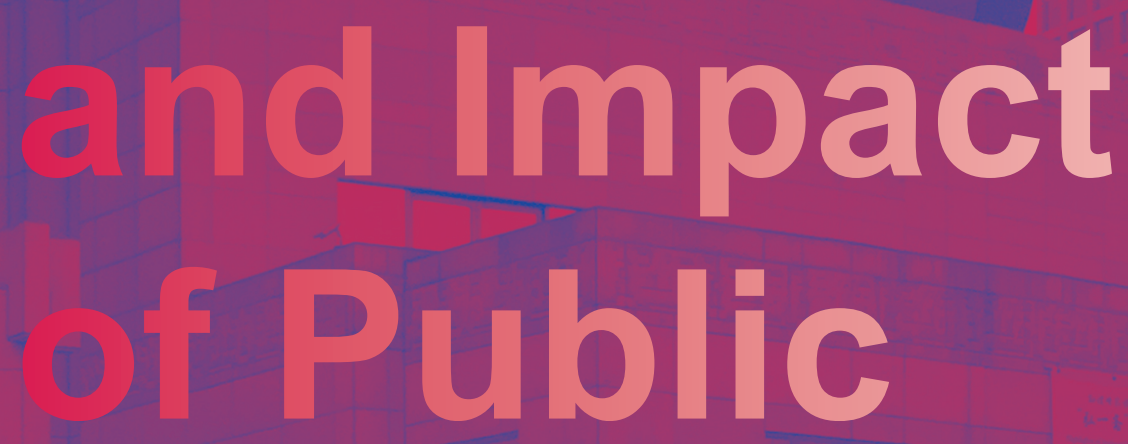

Museums

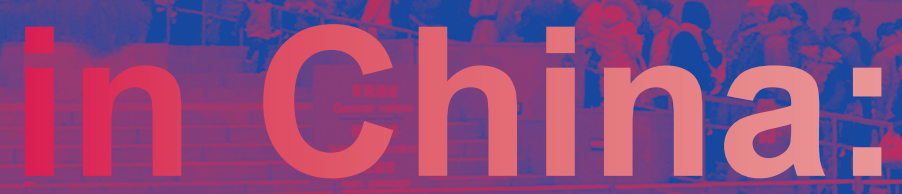

\section{Exploring}

New Trends

\section{Challenges}

by Sofia Bollo and Yu Zhang 
ofia Bollo has an academic background

in Chinese Studies. She holds a B.A.

in Chinese Language and Culture from the University of Turin and an M.A. in Chinese Studies from the School of Oriental and African Studies in London. She also gained work experience in diverse museum institutions in the UK and Italy. She obtained her Ph.D. from the University Research Priority Program (URPP) Asia and Europe at the University of Zurich, to which she is currently affiliated to publish her Ph.D. thesis. Her research on museums in China focuses on museum-elaborated narratives about the country's prehistoric past. Her study aims to explore the uses of the past in the present, through displays of archaeological collections of Neolithic Pottery in museums in China.

U Zhang has an M.A. in Cultural and Media Management from Institut d'Études Politiques de Paris, France and a B.A. in French Literature from the University of International Studies of Shanghai, China. With experience in event management and publishing, she occupied different roles at the International Council of Museums (ICOM), where she worked as Head of the Communications Department between 2013 and 2016. Since 2016, she works as a museum consultant and in 2017 she founded Yu Culture, a Paris-based company that provides consulting to cultural institutions on their China-related projects and partnerships. She lectures on Chinese museums and trends in the Chinese cultural sector regularly. 
In China, one of the main roles of museums is to provide a 'patriotic education' through the commemoration and celebration of

Chinese history. (a) $\mathrm{n}$ a commercialised and globalised China, museum institutions represent pivotal elements in public strategies to present and create national awareness and identity, insofar as their vast collections provide symbols of cultural identification. Chinese legislation identifies one of the main roles of museums as 'a basis for patriotic education' through the commemoration and celebration of Chinese history. The aim is to promote Chinese heritage on both a national and an international level. Despite the many intellectual and scholarly efforts at interpreting Chinese history, the fact is that provincial, regional, and increasingly commercial and private interests, guide most decisions on public historical displays.

Museums in contemporary China are undergoing a reconfiguration of policies in order to adapt to the needs of the market economy, for which new legislation is attempting to pave the way. In the programmes that Chinese museums develop, the need to comply with the different missions of museums (as defined by ICOM) is doubled with Chinese political directives, among which The Internet + Chinese Civilisation and Let cultural relics tell their stories. Meanwhile, new joint projects in the museum and heritage sectors, constant technological advancements, international exhibitions and cultural exchanges are increasing-less as a need for economic sustainability than as a means to establish Chinese cultural diplomacy.

This article will explore current museum policy in China and its impact in Chinese museums, with a focus on public museums, in order to better highlight the trends and challenges brought about through cultural policy. The analysis will be based on facts and figures illustrated by case studies, and supported by the use of first-hand material from interviews and informal conversations with museum professionals, as well as small-scale visitor surveys.

\section{Background}

$\mathrm{O}$ ver the past decade, the number of museums in China has grown exponentially, with an average of one new museum every day. Three distinctive monographs, published in 2014, are dedicated to contemporary museums in China: Kirk Denton (2014) describes the political and propaganda role of museums in China in his study on their representation of the past, Marzia Varutti (2014) has undertaken a thorough study of representation practices in heritage policy and nationalist narratives with valid cases of ethnic minorities displayed in museums, and the analysis of Tracey $\mathrm{Lu}$ (2014) focuses on notions of identity materialised through museum collections in China.
$T$ he first legal document to set up the framework for the ownership of all archaeological objects was issued in 1930 under the Law on the Preservation of Ancient Objects (古物保存法, guwu baocun $\mathrm{fa}$ ). It also regulated the registration system of private collections and artefacts trade (Li 1996). In Mao's China, the politics of display operated as a state in power and as a state in revolution (Ho 2017). Since China's outwardlooking vision, which led to the Reform and Opening-up in 1978, the number of museums grew steadily and, by 1980 , approximately 365 museums existed in China (Lü 2004). In the 1990s, a thousand more museums were established and consequently legislation on museums and specific treatises on museology flourished (Lü 1995; Wang 1990; Wenhuabu wenwuju 1985).
The role of the State Administration of Cultural Heritage

The current Law on the Protection of Cultural Relics (文物保护法, wenwu baohufa, hereafter Cultural Relics Law) was promulgated in 1982 during the National Congress, and recently amended at the 14th Meeting of the Standing Committee of the Twelfth National People's Congress on 24 April 2015 (SACH 2015b). The State Administration of Cultural Heritage (国家文物局, guojia wenwuju, SACH) within the Ministry of Culture regulates the value of both material culture and most public museums. According to this legislation, movable heritage objects (文物, wenwu) - a Chinese term often translated into English as 'cultural relics'-are categorised into four grades of value, from Grade 1, 'most rare and valuable' to Grade 4, 'ordinary' (Lau 2011).

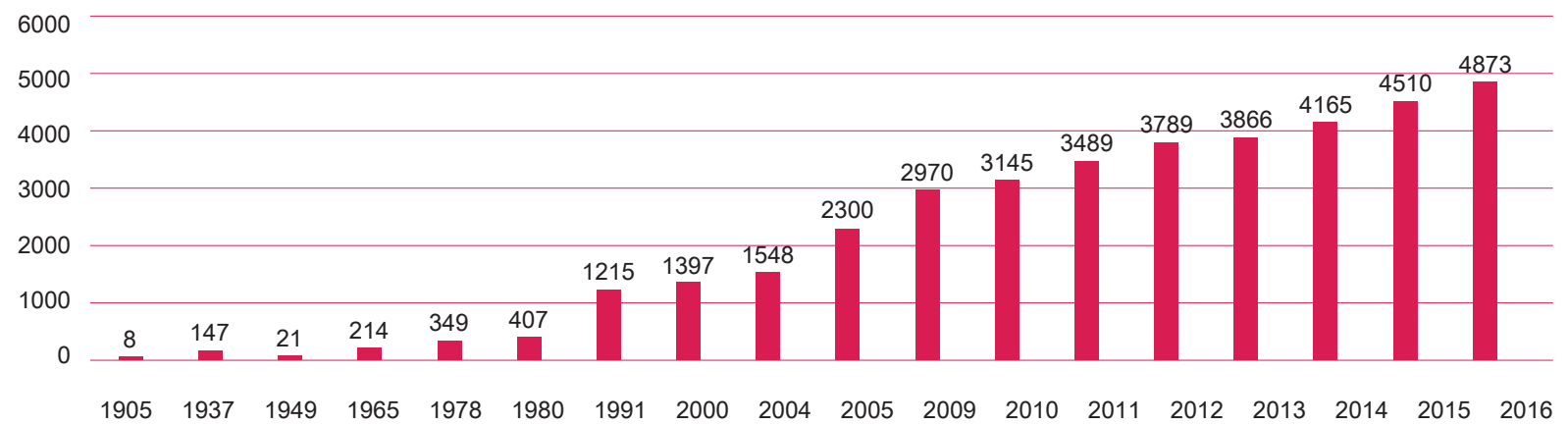

Fig. 1. The number of museums in China (1905-2016). (c) State Administration of Cultural Heritage (SACH) 


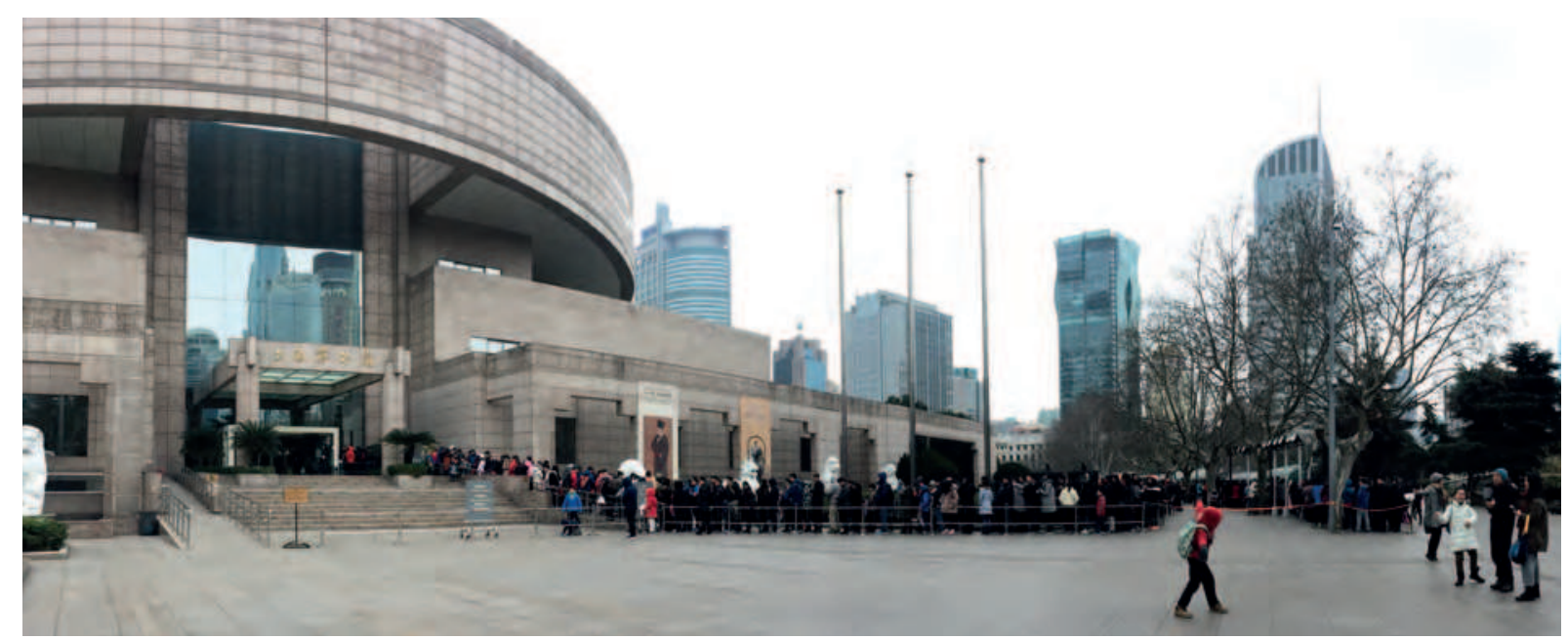

Fig. 2. Queues outside the Shanghai Museum for an exhibition during the Chinese New Year in 2017. () YZ / Yu Culture

The same body also breaks down

Chinese public museums into three categories: the best museums are classified as First, Second or Third Grade. This hierarchy of public museums is established according to quantitative criteria related to general management, facility, collection management, research, exhibitions and public services. This classification method, which was introduced in 2009, is used to distribute public funding to museums throughout the country. A re-evaluation of public museums takes place every four to five years and museums can be downgraded if deemed inconsistent with government criteria.

In 2012, after the first evaluation, 100 1 museums were ranked First Grade, 222 Second Grade and 438 Third Grade. According to the latest evaluation in 2016, there are currently 130 museums ranked First Grade (four were downgraded in 2013 and 34 were promoted to First Grade). It is to be noted that there is no clear distinction between the terms 'public' (公立, gongli) and 'stateowned' (国有, guoyou) museums within legal documents at the moment and the two terms are used interchangeably. The number of museums evaluated is insignificant compared with the overall number of museums in China (Fig. 1). SACH is expected to evaluate all public museums in order to create a benchmark and a standard on museum collection, facility and management.

\section{International partnerships}

nother conservation charter was Ainitially developed through a collaboration that began in 1997 between $\mathrm{SACH}$, the Getty Conservation Institute (GCI) and the Australian Heritage Commission as institutional partners, which ended in 2000 with the creation of the Principles for the Conservation of Heritage Sites in China (中国文物 古迹保护准则, hereafter the China Principles). The China Principles were finally issued by the Chinese National Committee for the International Council of Monuments and Sites (ICOMOS) and approved by $\mathrm{SACH}$ in 2000 . It took 10 years to implement the Principles, and in 2010 the Chinese ICOMOS committee began a revision of the document, which was completed in 2015 (ICOMOS China 2015).

A ccording to the Mid to Long-Term Museum Development Plan (20112020), China intends to open one museum per area of 250,000 inhabitants in order to cover the maximum population in terms of cultural offer, hosting 30,000 temporary exhibitions and attracting one billion visitors annually by 2020 . As of 2016 , there are 4,873 registered museums in China, 363 more than the previous year, 1,297 of which are private museums, accounting for almost one third of the country's total (Mengjie 2017). In 2016, some 30,000 temporary exhibitions were held in museums and cultural institutions, and the current quota is already one museum per 330,000 inhabitants (Figs. 1 and 2). Chinese public museums registered 900 million visitor entrances, which is an 8.7 per cent increase from the previous year (Ning 2016).

\section{Museums flourishing}

The opening of new museums can be explained by a number of factors. Firstly, the development of museums in China is the result of favourable measures in terms of financial and cultural policy. These incentives were accompanied by other initiatives: I) local councils started looking to the Bilbao model to attract tourists with new cultural landmarks through the extension of existing museums; II) the opening of trade or industrial museums by (former) state-owned companies, and III) the inauguration of specialised museums, e.g. science and technology, natural history, art, contemporary art, folk art, ethnology, industrial heritage, 21st century heritage, intangible heritage, as well as the multiplication of private museums.

The increase in the budget allocated to culture was pivotal for the growth of museums. Some 140 billion CNY (21.7 billion USD) in public funds were allocated to cultural heritage protection from 2011 to 2015. In addition to central government support, public museums also received subsidies from local government, while private museums can apply for local government funding on a project basis. Museum development is also due to an increase in archaeological excavations: new archaeological discoveries often lead to the establishment of site museums. By 2006, SACH listed a total of 2,351 archaeological sites and historical monuments as National Major Heritage Protection Units. 


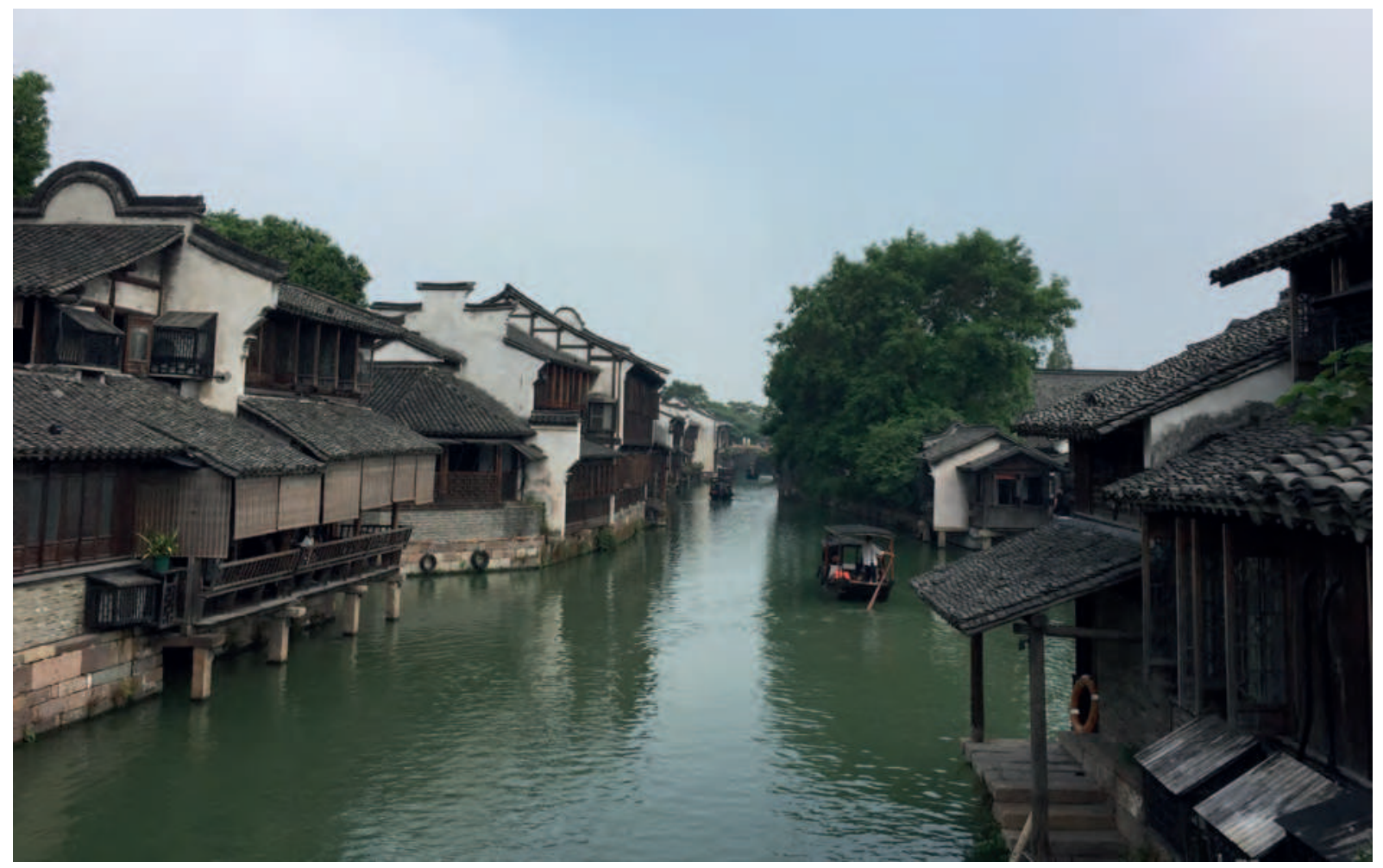

Fig. 3. Wuzhen has evolved from a water town to a popular and authentic tourist destination, making it a model for other Chinese villages. (c) YZ / Yu Culture, 2017

f 'musealisation' is understood as the operation of 'trying to extract, physically or conceptually, something from its natural or cultural environment and giving it a museal status, transforming it into a musealium or "museum object", that is to say, bringing it into the museal field', it can be argued that China is currently undergoing a 'musealisation' process (Desvallées and Mairesse 2010, p. 50). The soft power of museums to attract audiences, investments, tourists and economic development is definitely a key element in understanding the musealisation of China. One of the most influential strategies implemented in order to attract a wider public was free admission policy.

\section{Encouraging visitor attendance}

C rom 2009 onwards, visitors enter - without paying in all 1,804 stateowned museums. Over 120 Chinese museums have over one million visitors per year, mainly due to this free admission policy. In 2015, 3,717 museums, including state-owned, professional and private museums, have started offering free admission to the public. State-owned museums receive national subsidies, as an economic contribution to compensate for a lack of earnings due to free admission.
$T$ he increasing number of museums and free admission policies were also intended to draw the Chinese middle-class to museums, an affluent and well-educated population seeking ways to return to their roots through the arts and culture by attending exhibitions and joining educational activities. In addition, this development provided ideological tools for the 'Chinese Dream.' The value of heritage has also been applied to local economic development through the promotion of cultural tourism. Tourism is developing as a leisure activity within an expanding economic industry, as will be discussed later in the article.

notable example of musealisation Aand cultural tourism can be found in the 2016 No. 1 Central Document, an annual report on developments in key policy published by the Central Committee of the Communist Party of China and the State Council (MOA 2016). In this report, the government emphasises the importance of preserving historic settlements and building 'beautiful and liveable villages', which led to the revitalisation of Chinese traditional villages. Prominent Chinese architects have been involved in these projects to advise on the consolidation of old houses, re-planning of the villages and creation or repurposing of spaces, especially for community and cultural activities.
This requires that the villagers' needs be taken into account throughout the whole process. Such projects were launched even before the government directives were made official. For example, in Henan Province, a Cereals and Oils Museum and Village Activity Centre was created. Some villages opt for cultural tourism, in the hope that attracting visitors, whether domestic or foreign, will help create jobs and generate income.

The Wuzhen Model is one example. With its international arts festival, attended by renowned contemporary artists, Wuzhen, a town of around 60,000 people in the eastern province of Zhejiang, has become a talking point. (Fig. 3). Following years of infrastructural renovation that began in 1999, Wuzhen is now home to a rich artistic community and even hosts a number of high-profile events, including a contemporary art festival, a theatre festival, and the World Internet Conference (Zheng and Wang 2012). 
Fig. 4. Chinese museums have developed merchandising lines. (c) YZ / Yu Culture

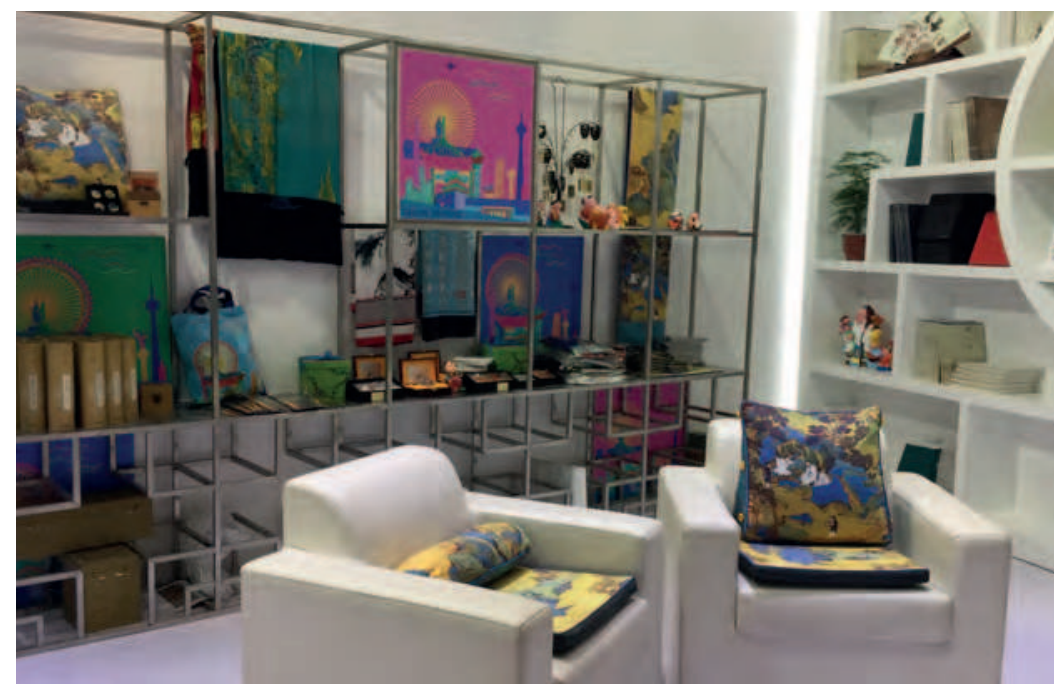

with regard to the creation of non stateowned museums and requires local heritage institutions to coordinate the creation of new museums (Wenbozaixian 2017).
The Thirteenth Five-Year Plan

$\Lambda$ s part of the Key Tasks for State AAdministration of Cultural Heritage in 2017, under the country's Thirteenth Five-Year Plan, an annual evaluation system will take into account the protection of cultural heritage at local levels, and local authorities will be held accountable for negligence, if they fail to protect cultural heritage.

n the Five-Year Plan, other measures include:

- encouraging the cultural creativity industry (so far, income from museum shops and products represents 10 per cent of the global income of museums);

- increasing employment and the number of qualified museum workers in the cultural heritage sector;

- increasing protection of immovable cultural heritage and establishing a compensation scheme for cities abundant in such cultural resources and for private collectors who want to conserve their valuable objects;

- stressing preventive conservation;

- encouraging more social involvement in the cultural sector economy.

\section{A youth-oriented museum experience}

To support organisations in developing cultural products, the State Council has issued general guidelines for several departments, including the Ministry of Culture and the Ministry of Finance. This document encourages national and regional cultural organisations (including museums, art museums, libraries) to experiment with cultural products and allows them to set the prices of these products, to license intellectual property and to establish commercial enterprises to manage cultural products. On a national level, the other general directives that are to be applied to museums are: Internet + Chinese Civilisation or Let cultural relics tell their stories (Su 2017). Museum games or mobile applications, merchandising products inspired from museum collections as well as edutainment are among many examples of how museums comply with the Internet + Chinese Civilisation and Let cultural relics tell their stories directives (Fig. 4).

$T_{\mathrm{P}}^{\mathrm{h}}$ he lagging development of cultural products until recently results from a number of factors: for instance, public museums in China are required to operate on a not-for-profit basis. In addition, investment in developing cultural products was not covered by government funding and most museums in China did not include this expense in their operating budgets. At the same time, museums fail to exploit their collections and undertake market research to develop interesting products.
Chinese museums are required to adapt to the needs of the dynamic market economy, alongside a reconceptualisation of cultural heritage values. 


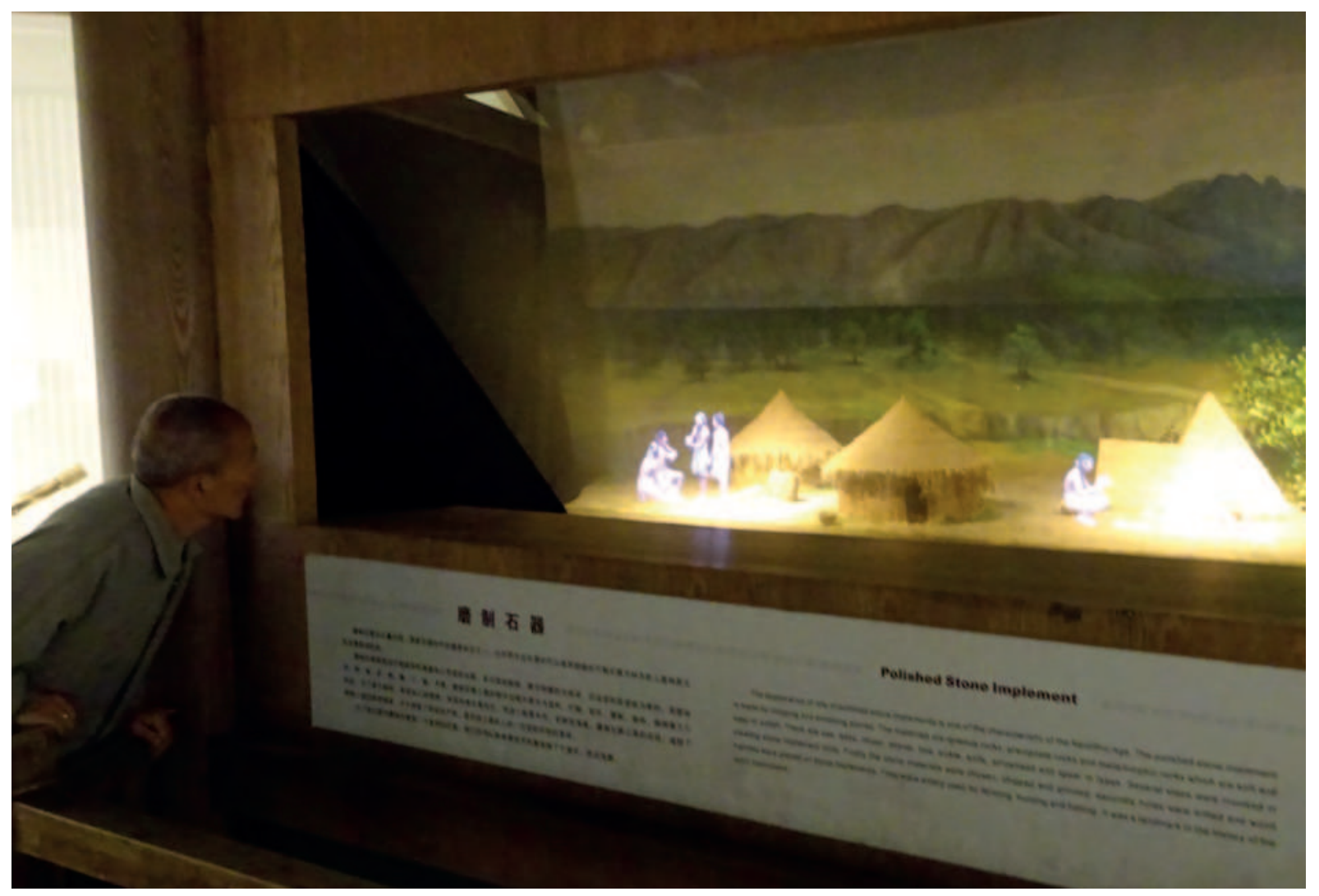

Fig. 5. A visitor engaging with a hologram interaction video in Banpo Site Museum, 2015. ๑ Sofia Bollo

$B$ y connecting with a young and internet-savvy public, museum games and mobile applications seem to be particularly popular: the Palace Museum has developed several games and applications for its permanent collection, temporary exhibitions and education programmes. With more than 8,700 types of cultural products generating more than one billion CNY (144 million USD), the Palace Museum has become the pioneer in connecting its centuries-old collection to the public. Other museums have followed the trend by inviting designers or associating with existing brands to explore their vast collections and improve their narrative skills through digital technology and merchandising. While free admission policy and the annual evaluation of museums have both discouraged museums to charge for their permanent collections, they have achieved revenue diversification by complying with market needs through merchandising (Fig. 5).
$T$ he Thirteenth Five-Year Plan also includes measures to enhance the protection of cultural heritage and its promotion overseas in all channels and at all levels. Several high-level government meetings were held since the outlining of the plan, while top Chinese officials including President Xi Jinping and Prime Minister Li Keqiang also stressed the importance of cultural heritage protection and international cooperation (Wang 2016). In July 2016, the Chinese Museums Association, a government-organised NGO (or GONGO) supervised by $\mathrm{SACH}$, created an online platform to facilitate the exchange of information among museum networks. ${ }^{3}$ It is 'a bridge between Chinese museums and their international partners for exhibition exchanges' (Chinese Museums Association Exhibition Exchange Platform 2016). The platform introduces Chinese exhibitions to the world and showcases international exhibitions for Chinese museums, nurturing international dialogue by encouraging more Chinese artefacts to be shown in foreign institutions via a 'China in Cultural Relics' programme.
Incentives for tourism development The material and symbolic significance of museums have international value in terms of tourism, conservation/ preservation and cooperation interest. For example, in Shaanxi Province, which is regarded as an 'important archaeological region', a Cultural Heritage Promotion Centre coordinates international relations for all institutions in the province. A dedicated team manages object loans for international exhibitions, mainly the Terracotta Warriors international travelling exhibition. A museum educators' network has also been set up recently to share best practices. In addition, every year the ICOM International Training Centre for Museum Studies (ICOM-ITC) organises workshops for museum professionals managed and housed at the Palace Museum in Beijing. 


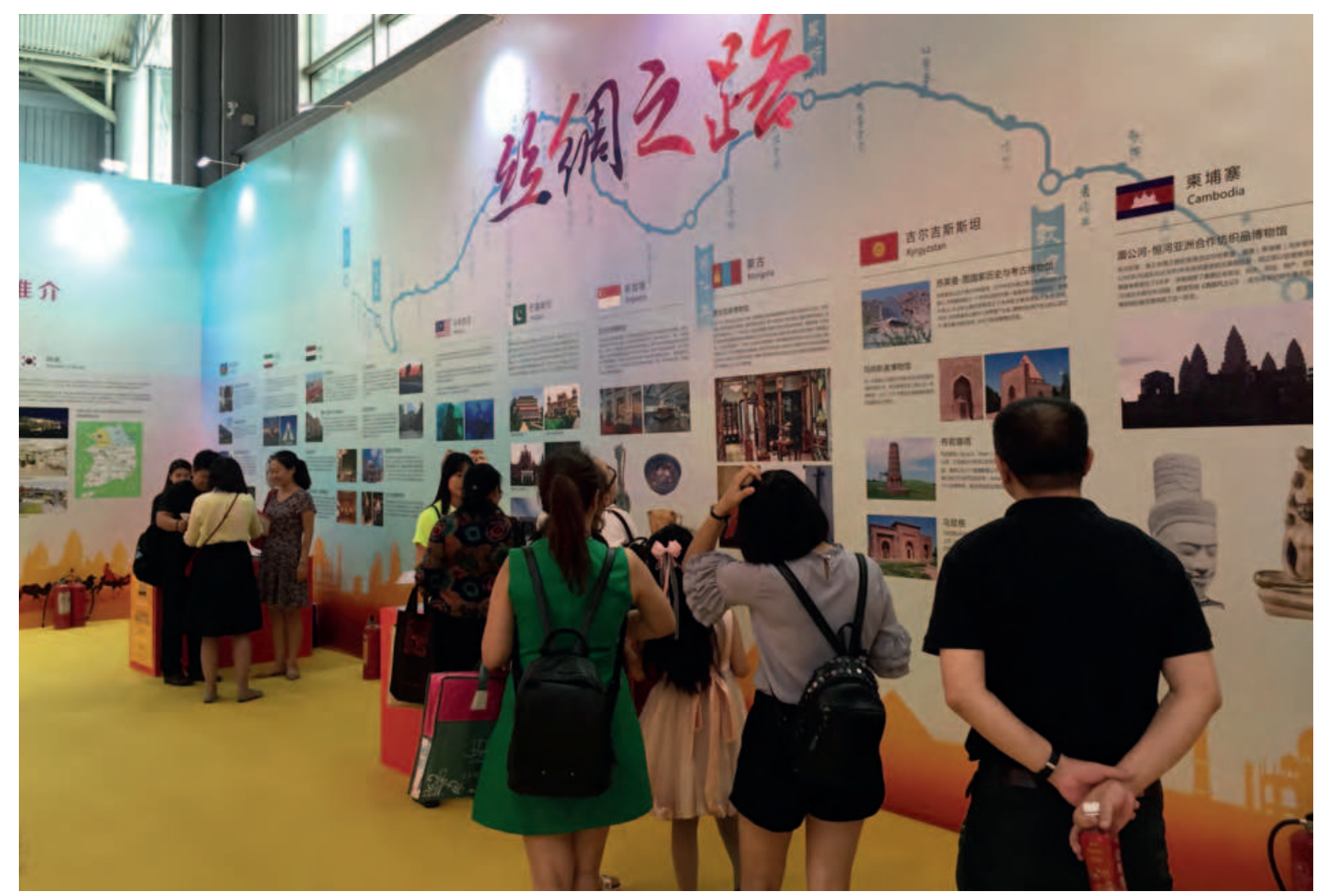

Fig. 6. The Chinese Museums Association hosted a showcase booth about heritage on the Silk Road as its response to supporting the OBOR initiative, during its conference in 2016. () YZ / Yu Culture

$\Lambda$ clear example of how culture and Aheritage play a role in international cooperation is also illustrated in the Silk Road, a 'cultural route' that enabled cultural exchanges and a shared heritage. Its most recent reworking in international diplomacy is called 'One Belt, One Road'. ${ }^{4}$ Launched in 2013, this geopolitical initiative is also entangled with cultural diplomacy (Sidaway and Woon 2017). Nurturing a sense of shared history in specific regions creates politi$\mathrm{cal}$ and economic cooperation and mutual loyalty (Fig. 6). Scholars believe that 'heritage diplomacy' will increasingly allow for the reshaping of history, trade, infrastructures and even security across countries (Winter 2016).
$\mathrm{N}$ ew museums, cultural heritage protection projects, exhibitions, festivals and intangible heritage initiatives can all apply for the Silk Road Fund, a state-owned investment fund founded in 2014. Notable examples include a joint excavation mission between Chinese and Uzbekistani archaeologists since 2012. This is China's largest archaeological project in a foreign country. The mission is coordinated by the relevant academy of Social Sciences in each country, and a museum is planned near the archaeological site.

These new trends, domestic directives, international joint exhibition projects and cultural exchanges for the museum and heritage sectors, together with constant technological advancements and financial strategic incentives, are implemented to a greater extent, responding to a need to establish cultural rather than economic diplomacy for China.

\section{Nurturing a sense of shared history in specific regions creates political and economic cooperation, and mutual loyalty.}




\section{Challenges}

There are limitations to the current

Chinese museum system reflected in the emerging trends described above. Indeed, public museums and tangible cultural heritage are under the supervision of a hierarchical and centralised state administration (Fig. 7). There is a geographical hierarchy of Major Heritage Protection Units, divided into three levels within SACH: National, Provincial, and Municipal/County Major Heritage Protection Units.

A s Figure 7 shows, cultural heritage authorities managed less than twothirds of Chinese museums in 2014. Public museums and cultural institutions, depending on their history and type of collection, often answer to different ministries and authorities, both nationally and locally. On an international level, in addition to the programmes undertaken directly by museums, the many overseas Confucius Institutes (managed by the Ministry of Education), the culture section of Chinese embassies (by the Ministry of Foreign Affairs), as well as overseas China Cultural Centres (by the Ministry of Culture), can carry out cultural exchange activities. The segmentation sometimes results in ambiguous managerial conditions and therefore a lack of coordination in cultural diplomacy (Lai 2015; Zan and Bonini Baraldi 2013).

$\mathrm{O}$ verlapping responsibilities, segmented management across various government and local agencies, or blank areas represent a major challenge for Chinese museums. For example, art museums, which fall into different categories depending on their collection, are managed differently according to their location; furthermore, there are specific museums administered directly or indirectly by the Chinese Central Military Commission, such as the Chinese Aviation Museum and the Military Museum of the Chinese People's Revolution. University museums present a notable dilemma: they do not hold a legal entity and depend on specific universities-which are placed under the Ministry of Education in most casesthat are in general not familiar with museum matters and do not assign them with a dedicated permanent staff. They seldom benefit from support offered to 'cultural heritage museums' and do

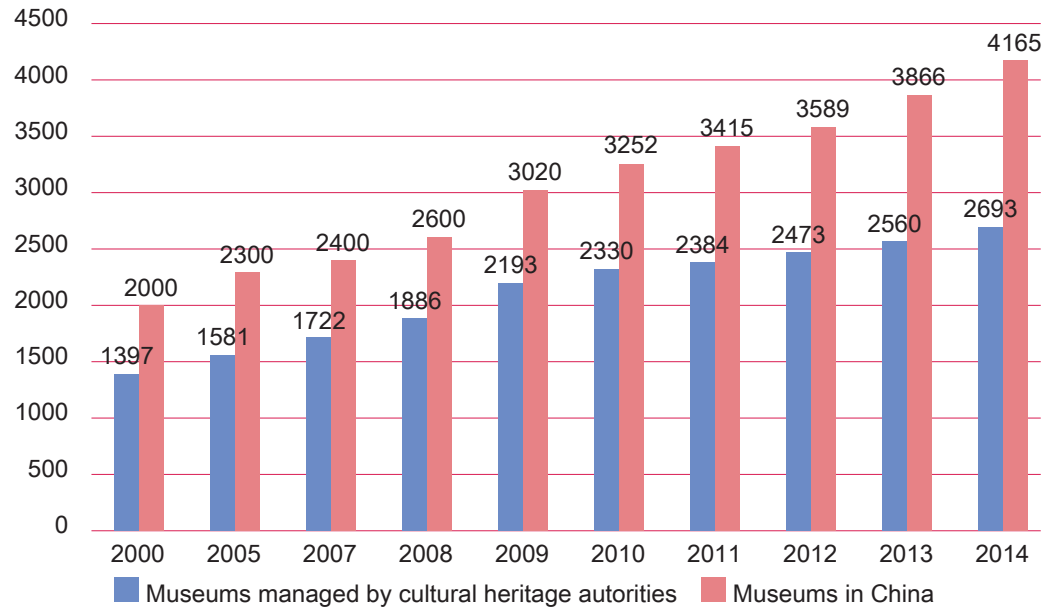

Fig. 7. Number of museums managed by cultural heritage authorities (2000-2014).

(c) State Administration of Cultural Heritage (SACH)

not enjoy fiscal benefits such as tax reduction for the acquisition of museum collection.

\section{External partnerships}

ther actors involved in the museum system include NGOs, and GONGOs: the powerful Chinese Association for Science and Technology, with its hundreds of societies, directly or indirectly manages the science and technology museums, botanical gardens, observatories, etc. Meanwhile, some of the most important museums in China answer directly to specific Ministries: for example, the Palace Museum, the National Museum and the National Art Museum report directly to the Ministry of Culture, and the Geological Museum of China to the Ministry of Land and Resources.

$B$ contrast, most of the state-owned provincial museums are managed locally or regionally, where Chinese provinces tend to compete for financial resources and cultural pride. This apparent separatism of singular provincial cultural institutes, particularly in archaeological institutions, can be as well considered as a means to gain particular support and legitimacy from the central government, in what has been called a 'regionalist paradigm' (Falkenhausen 1995).

\section{In China, traditional}

concepts of history and civilisation are

moving towards

different functional

and educational goals. $\mathrm{n}$ the most recently revised version of The Past is a Foreign Country, David Lowenthal (2015) extensively covers various modalities and reasons why the past can be made relevant in the present. The recovery, preservation, commemoration and fabrication of the past are some of the most relevant attitudes observed in China. Museums and exhibitions act as the validation and regulation of cultural heritage and thus promote a vision of nationalism, enjoy a range of institutional and didactic endorsements, and have become sites for ideological assertion (Denton 2014; Lu 2014; Varutti 2014).

\section{Making education a priority}

In the Cultural Relics Law enforced in 2015, education appeared again as one of the main functions of museums (Wang 2004).5 Currently the articulation of the pedagogical role states that museums will teach and educate people under specific modalities, i.e. through the commemoration and celebration of Chinese history, so as to promote Chinese heritage, both on a domestic level and an international one in order to revive cultural nationalism (Guo 2007).

$\mathrm{M}$ useums are authorised to interpret national history, make a selection and create a representation of the society for the society (Bennett 1995). In China, traditional concepts of history and civilisation are moving towards different functional and educational goals; these exploit the past and multiculturalism as tools for establishing new nationalistic features of Chinese cultural identity that is then promoted and enshrined in comprehensive Chinese public museums (Bollo 2017). 


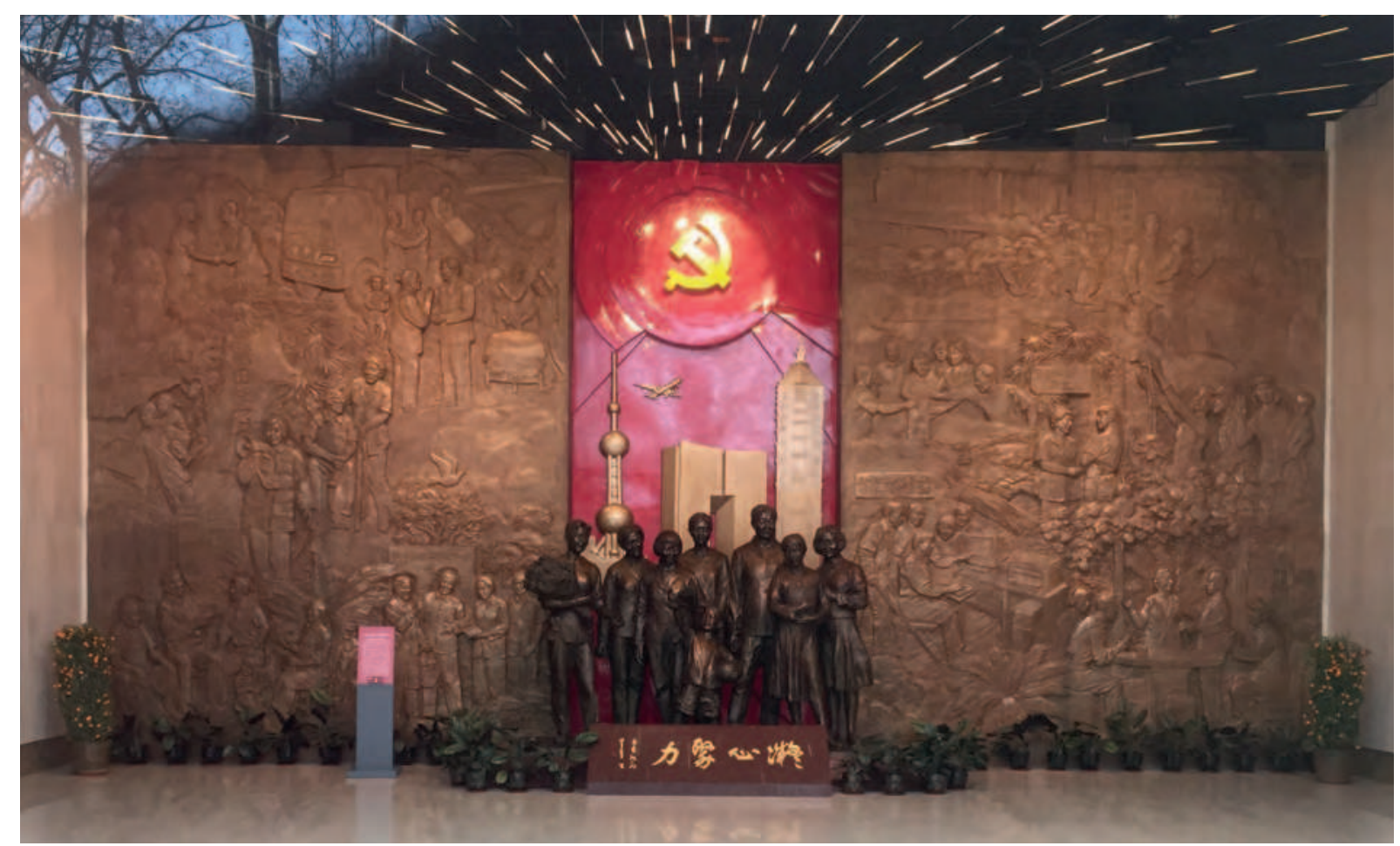

Fig. 8. The Shanghai Cohesion Project Museum is a 'basis of patriotic education'. Opened in 2013, propaganda about the care of the party and the government of the population is shown through archives, photos and objects. ๑ YZ / Yu Culture, 2016

resent-day Chinese nationalism includes the glorification of cultural remnants of the past in a form of new antiquarianism, which become instrumental in nurturing patriotism and promote the enjoyment of cultural consumerism and leisure activities (Falkenhausen 2014). The soft power of museums inevitably affects the social and cultural alignment of people, has an impact on actions and ideas about what is worth remembering, and might be the cause of potential censorship. In China nowadays, museums remain an important part of the active expression of values and the dissemination of state ideology, which required them to adjust accordingly (Fig. 8).

\section{Setbacks: visitors' perspectives}

useums in China are effective poV tential education tools. A small survey conducted in 2015 on a selection of public museums in China has shown that visitors generally have a positive attitude towards the exhibition content and messages. Nevertheless, many complaints were registered about museums being too crowded and negatively affecting the overall museum experience (Bollo 2017). This is another big challenge brought forward by the free admission policy. In order to overcome the downside of the free admission policy, many museums in China have therefore decided to set an upper limit for daily visitors. For instance, the Palace Museum has limited its daily visitor number to 80,000 and was the first to decide on a specific closing day each week, to undertake restoration and reparation work otherwise impossible with the constant visitor flow.

longside the Chinese government's

A effort to promote nationalism, commercial and private interests increasingly dictate measures on most public displays. The foreword to the China Principles states that: ${ }^{6}$

China is employing a new model

for the establishment of these

[archaeological] sites based on archaeological research that balances conservation and use, provides for a site's interpretation and presentation, protects the interests of various stakeholders, and is beneficial for developing tourism and improving the lives of the local community (ICOMOS China, 2015, p. 54).

\section{Investment, commodification and} cultural heritage preservation

ompared to the Cultural Relics Law, the China Principles lay stronger emphasis on the economic value of cultural heritage. This assertion encouraged the growth of more Public-Private Partnerships (henceforth, PPPs) in areas of cultural heritage management. A case study of Shandong Province shows how the state is still seeking to divest itself of economic complexities by turning management over to the private sector
(Flath 2002). PPPs in China usually imply outsourcing, concession and divestiture. On the managerial level, however, problems connected with the interaction of public and private enterprise are becoming more frequent, as usually each pursue separate goals (Gray 2015). The first 11 PPP pilots in the cultural sector include the construction and management of county-level cultural centres and the development of cultural tourism by constructing heritage parks and new museums. Museums are confronted with commercialisation of public history, which might lead to the commodification of cultural heritage (Falser and Juneja 2013).

n many parts of China, historical preservation and real estate investment have resulted in tourism gentrification (Liang and Bao 2015; Shin 2010; Zhao 2009). Tourism is becoming the main driving force in economic, social, cultural, and lifestyle transformations. One of the best-known private tourism corporations is Shenzhen OCT Tourism Development Co. Their slogan is 'Originating in real life and rising above it, discarding the dross and selecting the essential' (Liang and Bao 2015). In becoming national monuments, it is increasingly likely that archaeological sites will be transformed into large parks and lucrative tourist attractions (Leibold 2012; Murowchick 2013). 
E urthermore, the value of heritage has been accepted and reassessed by the Chinese government, and UNESCO acknowledges Chinese preservation efforts, which are recognised on a global scale, bringing international prestige. The Authorized Heritage Discourse (AHD), connected to UNESCO, stresses the inherent value of heritage: ' $t$ ] he authorized heritage discourse focuses attention on aesthetically pleasing material objects, sites, places and/or landscapes that current generations 'must' care for, protect and revere so that they may be passed to nebulous future generations for their 'education', and to forge a sense of common identity based on the past' (Smith 2006, p. 29). However, the efforts of preservation of history transform state authorities as caretakers of a national cultural heritage, and justify their means. It has been argued that these measures do preserve the 'universal' heritage of the past, while they simultaneously ignore present social realities (Shepherd 2009).

Tr he commodification of cultural artefacts and the promotion of narratives of unbroken continuity in the development of Chinese civilisation within museum exhibitions also demonstrate that curatorship is still subject primarily to consideration of tourism and patriotism rather than to current scholarly standards (Fiskesjö 2015). In many cases museums in China have to find a difficult balance between maintaining historical accuracy and achieving economic growth.

uch phenomena of managerial seg$\checkmark$ mentation, cultural nationalism, commercialisation and commodification represent actual challenges for museums in China nowadays, and have led scholars to describe the country's 'museum boom' as an exaggerated form of 'musealisation', even using the pejorative term 'museumification' (Johnson and Florence 2013).

\section{his article has provided an overview of Chinese policy in relation to museums, by exploring the current status of the museum system, the implementation of measures to adapt to market economy needs and to comply with government directives, and the resulting limitations.}

In describing both successful new trends in museum policy as well as challenges they present, this paper provides a fresh perspective on the existing discussion on the Chinese museum system, and its role and impact on both domestic and international levels. The Chinese museum system responds to different domestic needs and combines strong international cultural policies. In the coming years, museums in China will develop further adapting to local market economy and national political directives, while they increasingly expand their influence and connections at an international level.

\section{Notes}

1 The above-mentioned monographs and other research are symptomatic of the growing interest in the topic of museums in China in different academic fields. 2 The 'Chinese Dream' is a term that was coined by Chinese President Xi Jinping and became increasingly popular. It describes a set of personal and national ideals, which are required to build a prosperous society and realise national rejuvenation.

3 A 'government-organised nongovernmental organisation' (GONGO) is an organisation that is set up or sponsored by a government in order to preserve state power, further its political interests, and mimic the civic groups and civil society at home, or promote its international or geopolitical interests abroad (see also Naim 2009).

4 The 'One Belt, One Road' (or, OBOR), in Chinese, is referred to as 一带一路, yi dai yi lu. More recently, Chinese authorities have adopted the wording 'Belt and Road Initiative' in English.
5 In Chinese, the role of museums as 'basis of patriotic education' is written as 爱国主 义教育基地, aiguo zhuyi jiaoyu jidi (SACH 2015a), where the term 'patriotism' is literally translated as 'love for the country' (爱国, aiguo).

6 The foreword of the China Principles was published in 2015 and was written by the former President of ICOMOS China and Deputy Director of SACH China, Tong Mingkang.

\section{REFERENCES}

> Bennett, T. 1995. The Birth of the Museum: History, Theory, Politics. London: Routledge.

> Blumenfield, T. and Silverman, H. (eds). 2013. [Online]. Cultural Heritage Politics in China. New York, NY: Springer. Available at: http://link.springer.com/10.1007/978-14614-6874-5 [accessed 27 July 2016]. > Bollo, S. 2017. Enshrining Neolithic Pottery? Narratives of the Prehistoric Past in Contemporary Museums in China. Ph.D. thesis. University of Zurich.

$>$ Chinese Museums Association Exhibition Exchange Platform. 2016. [Online]. About the platform. Available at: http://en.chinamuseum.com/en/about [accessed 16 July 2017].
> Denton, K.A. 2014. Exhibiting the Past: Historical Memory and the Politics of Museums in Postsocialist China. Honolulu: University of Hawaii Press.

> Desvallées, A. and Mairesse, F. 2010. Key Concepts of Museology. Paris: Armand Colin.

> Evans, H. and Rowlands, M. 2015. Reconceptualizing Heritage in China: Museums, Development and the Shifting Dynamics of Power. In: P. Basu and W. Modest (eds), Museums, Heritage and International Development. New York:

Routledge, pp. 272-294.

> Falkenhausen, L. von. 2014.

Antiquarianism in East Asia:

A Preliminary Overview. In: World Antiquarianism: Comparative Perspectives. Los Angeles: Getty Research Institute. > Falkenhausen, L. von. 1995. [Online]. The Regionalist Paradigm in Chinese Archaeology. In: P. L. Kohl and C. Fawcett (eds), Nationalism, Politics and the Practice of Archaeology. Cambridge and New York: Cambridge University Press. Available at: http://dx.doi.org/10.1017/ CBO9780511558214.012.

> Falser, M. and Juneja, M. (eds). 2013. 'Archaeologizing' Heritage? Transcultural Entanglements between Local Social Practices and Global Virtual Realities. Berlin: Springer. 
> Fiskesjö, M. 2015. The Museum Boom in China and the State Efforts to Control History. Museum Anthropology Review, Vol. 9, No. 1-2, pp. 96-105.

> Flath, J.A. 2002. Managing Historical Capital in Shandong: Museum, Monument, and Memory in Provincial China. The Public Historian, Vol. 24, No. 2, pp. 41-59. > Gray, C. 2015. [Online]. The Politics of Museums. London: Palgrave Macmillan. Available at: http://www.palgraveconnect. com/doifinder/10.1057/9781137493415 [accessed 9 May 2016].

$>$ Guo, Y. 2007. [Online]. The Revival of Chinese Cultural Nationalism. PORTAL Journal of Multidisciplinary International Studies, Vol. 4, No. 1. Available at: http://epress.lib.uts.edu.au/journals/ index.php/portal/article/view/424 [accessed 20 December 2016]. > Ho, D.Y. 2017. Curating Revolution: Politics on Display in Mao's China. Cambridge: Cambridge University Press. > ICOMOS China. 2015. [Online]. Zhongguo wenwu guji baohu zhunze 中国文物古迹保护准则 [Principles for the Conservation of Heritage Sites in China]. Beijing: Wenwu chubanshe. Available at: http://hdl.handle.net/10020/ gci_pubs/china_principles_2015 [accessed 9 January 2018].

> Johnson, J. and Florence, Z.A. 2013. [Online]. The Museumification of China. 艺术界 LEAP. Making the Museum, Vol. 18. Available at: http://leapleapleap. com/2013/05/the-museumification-ofchina/ [accessed 9 January 2018]. $>$ Lai, C. 2015. Archaeological Museums and Tourism in China: A Case Study of the Sanxingdui Museum. Museum Management and Curatorship, Vol. 30 , No. 1, pp. 75-93.

> Lau, T. 2011. The Grading of Cultural Relics in Chinese Law. International Journal of Cultural Property, Vol. 18, No. 1, pp. 1-35.

> Leibold, J. 2012. Filling in the Nation: The Spatial Trajectory of Prehistoric Archaeology in Twentieth-Century China. In: B. Molough and P. G. Zarrow (eds), Transforming History: The Making of a Modern Academic Discipline in Twentieth Century China. Hong Kong: Chinese University Press, pp. 333-371.

> Li, G. 1996. Chutou kaoguxuejia de zuji Li Ji zhixue shengya suoji 锄头考古学家的 足迹: 李济治学生涯琐记 [Archaeologists, footprint: Recollection of the scholarly career of Li Ji]. Beijing: Zhongguo renmin chubanshe.

> Liang, Z.-X. and Bao, J.-G. 2015. Tourism Gentrification in Shenzhen, China: Causes and Socio-spatial Consequences. Tourism Geographies, Vol. 17, No. 3, pp. 461-481. $>$ Lowenthal, D. 2015. [Online]. The Past is a Foreign Country - Revisited. Rev. ed. Cambridge: Cambridge University Press. Available at: http://ebooks.cambridge.org/ ref/id/CBO9781139024884.

> Lü, J. 1995. Zhongguo bowuguan zhi 中国 博物馆志 [Records of Chinese museums]. Beijing: Huaxia chubanshe.
> Lü, J. 1995. Zhongguo bowuguan zhi 中国博物馆志 [Records of Chinese museums]. Beijing: Huaxia chubanshe. > Lü, J. 2004. [Online]. Zhongguo bowuguan shilun 中国博物馆史论 [Talks about the history of Chinese museums]. Beijing: Zijincheng chubanshe. Available at: https://book.douban.com/subject/1625181/ [accessed 28 July 2016].

> Lu, T.L.-D. 2014. Museums in China: Power, Politics and Identities. London and New York: Routledge.

> Mengjie. 2017. [Online]. Chinese museums receive $900 \mathrm{mln}$ visitors each year. Xinhua. Available at: http://news.xinhuanet.com/ english/2017-05/18/c_136295506.htm [accessed 30 July 2017].

> Ministry of Agriculture (China). 2016. [Online]. China's No. 1 Central Document 2016 - Ministry of Agriculture of the People's Republic of China (MOA). Available at: http://english.agri.gov.cn/ news/dqnf/201601/t20160128_164966.htm [accessed 17 September 2017.

> Murowchick, R.E. 2013. Despoiled of the Garments of Her Civilization: Problems and Progress in Archaeological Heritage Management in China. In: A. P. Underhill (ed.), A Companion to Chinese Archaeology. Chichester, West Sussex: John Wiley \& Sons, Ltd., pp. 13-34.

$>$ Naim, M. 2009. What is a gongo? In: Global Politics in a Changing World: AReader. Boston and New York: Cengage Learning, p. 222.

> Ning, J. (ed.). 2016. [Online]. China Statistical Yearbook. Beijing: China Statistic Press. Available at: http://www. stats.gov.cn/tjsj/ndsj/2016/indexeh.htm [accessed 20 July 2017].

> State Administration of Cultural Heritage (China). 2015a. [Online]. Bowuguan tiaoli 博物馆条例[Museum Act]. Available at: http://www.sach.gov. cn/art/2015/3/2/art_1034_117213.html [accessed 26 May 2016].

> State Administration of Cultural Heritage (China). 2015b. [Online]. Cultural Relics Protection Law of the People's Republic of China. (2015 Amendment) 中华人民 共和国文物保护法 (2015修正). Available at: http://www.pkulaw.cn/fulltext_form. aspx?Gid=252634 [accessed 25 May 2016]. > State Administration of Cultural Heritage (China). 2015c. [Online]. Decision of the Standing Committee of the National People's Congress on Amending the Cultural Relics Protection Law of the People's Republic of China (2015) 全国人大常委会关于修改 《中华人民共和国文物保护法》的决定 (2015). Available at: http://www.pkulaw. cn/fulltext_form.aspx?Gid=247411 [accessed 25 May 2016].

> Shepherd, R.J. 2009. Cultural Heritage, UNESCO, and the Chinese State: Whose Heritage and for Whom? Heritage Management, Vol. 2, No. 1, pp. 55-79.
> Shepherd, R.J. and Yu, L. 2013. [Online]. Heritage Management, Tourism, and Governance in China. New York, NY: Springer. Available at: http://link. springer.com/10.1007/978-1-4614-5918-7 [accessed 12 October 2016].

> Shin, H.B. 2010. Urban Conservation and Revalorisation of Dilapidated Historic Quarters: The Case of Nanluoguxiang in Beijing. Cities, Vol. 27, Supplement 1, pp. $\mathrm{S}_{43}-\mathrm{S}_{54}$.

> Sidaway, J.D. and Woon, C.Y. 2017. Chinese Narratives on 'One Belt, One Road' (一带一路) in Geopolitical and Imperial Contexts. The Professional Geographer, Vol. 69, No. 4, pp. 1-13. $>$ Smith, L. 2006. Uses of Heritage. London: Routledge.

> Su, J. 2017. [Online]. 国家文物局: 2017 年让文物自己讲故事 [SACH: 2017 Let the Cultural Relics Talk]. Zhongguowang Guoqing. Available at: http://guoqing.china. com.cn/2017-02/o9/content_40253388.htm [accessed 28 February 2017].

> Varutti, M. 2014. Museums in China.

The Politics of Representation After Mao. Woodbridge: Boydell and Brewer Ltd. > Wang, H. (ed.). 199o. Zhongguo bowuguan xue jichu (中国博物馆学基础 [Chinese Museology Foundations]. First edition. Shanghai: Guji Chubanshe. > Wang, H. 2004. Zhongguo bowuguan xue jichu (中国博物馆学基础

[Chinese Museology Foundations]. Shanghai: Guji Chubanshe.

> Wang, K. 2016. [Online]. Xi Says Protecting Relics a Priority. China Daily. Available at: http://www.chinadaily.com. cn/china/2016-04/13/content_24490576.htm [accessed 8 June 2017].

> Wenbozaixian. 2017. [Online]. Ruhe tuidong feiguoyou bowuguan fazhan? Guojia wenwuju gei yijian le 如何推动 非国有博物馆发展? 国家文物局给意见 了 [How to promote the developement of private museums? An idea from $\mathrm{SACH}$. Available at: https://mp.weixin. qq.com/s/hBkkuAB_snvGpHSoGsY_uA [accessed 17 July 2017].

> Wenhuabu Wenwuju. 1985. Zhongguo bowuguanxue gailun (中国博物馆学概 论 [Introduction to Chinese Museology]. Beijing: Wenwu chubanshe.

> Winter, T. 2016. Heritage Diplomacy along the One Belt One Road. The Newsletter, No. 74, pp. 8-10.

> Zan, L. and Bonini Baraldi, S. 2013. The Heritage Chain Management. General Issues and a Case Study, China. Journal of Cultural Heritage, Vol. 14, No. 3, pp. 211-218. > Zhao, Y. 2009. The Characteristics and Causes of Urban Tourism Gentrification: A Case of Study in Nanjing. Economic Geography, Vol. 29, No. 8, p. 1391.

> Zheng, S. and Wang, D. 2012. Research on Mode of Wuzhen Tourism Development [J]. Areal Research and Development, Vol. 5, p. 18. 